\title{
School of Empathy for Enhancing Children's Well-being
}

\author{
Nur Widiasmara, Resnia Novitasari, Nita Trimulyaningsih, and Marcus Stueck
}

\begin{abstract}
This study was aimed to examine the effects of School of Empathy on emotional and psychological well-being on elementary school age children in one of the public elementary schools in Yogyakarta. The study involved 13 children aged 9-14 years divided into 7 in children experimental group and 6 in children control group. This study used quasi experiment design with control group with pre-test \& post-test design. The instrument used in this study is the Indonesian version of the School of Empathy (SoE) module developed by Stueck et al. (2010) and the Emotional and Psychological Well-being Scale for Children adapted from The Stirling Children's Well-being Scale (Liddle \& Carter, 2015). Data analysis used parametric statistic independent sample t-test. The results showed that children's well-being score between the experimental group $(M=32.71, S D=3.904)$ and control group $(\mathrm{M}=33.83, \mathrm{SD}=4.956) ;(\mathrm{t}(11)=-0.456, \mathrm{p}=0.657)$, on the positive emotional state $(\mathrm{t}(11)=-\mathbf{0 . 5 4 0}, \mathrm{p}=\mathbf{0 . 6})$ and positive outlook $(t)(11)=-0.305, p=0.766)$. Effect size score of treatment (SoE training) on children's well-being $(r=0.136)$, positive emotional state $(r=0.160)$ and positive outlook $(r=$ 0.091). The conclusion of this study is that no differences between the experimental group and the control group. SoE training has little effect on emotional and psychological well-being. The results of the study are discussed further.
\end{abstract}

Index Terms-Children, emotional and psychological well-being, school of empathy.

\section{INTRODUCTION}

Primary school-aged children are expected to acquire the basic knowledge that is considered essential for the successful adjustment in life. In addition, children also need to learn certain important skills both curricular and extracurricular skills. However, it should not be too much and burdensome to children. It should not only the willingness of the parents but also based on the will of the child [1].

According to Alvin (2007) [2], children today are not like children in the last generation who have plenty of time to play after school with friends. In addition, the world of education today shows the phenomenon of accelerated child development. One of the characteristics is that children are given various extracurricular activities each week which aims to improve academic, social, sports, cultural and psychological skills.

Manuscript received November 25, 2017; revised May 1, 2018. This study was supported by Direktorat Penelitan dan Pengabdian Masyarakat, Universitas Islam Indonesia.

Nur Widiasmara, Resnia Novitasari, Nita Trimulyaningsih are with the Department of Psychology, Universitas Islam Indonesia, Indonesia (e-mail: nurwidiasmara@uii.ac.id, resnia.novitasari@uii.ac.id,nita@uii.ac.id)

Marcus Stueck is with DPFA Hochschule Sachsen Germany (e-mail: marcus.stueck@dpfa-hs.de)
Many children are too busy to take the time to play, do creative activities or relax after school. Children complain about all of their activities or refuse to follow due to schedule lessons and activities that are too crowded. In addition, many children are also too busy and complain about the density of activities and tasks at school. For example, cases that occurred in one of the Integrated Islamic Primary Schools in Klaseman, Sleman, found that a child who refused to go to school, has low self-esteem, and throw tantrums when leaving for school is because of the discomfort in school and the many tasks to be performed [3]. It shows the existence of the demands that cause stress, uncomfortable, and boredom in children at school. The inability of children to adapt to these demands will lead to stress in children [4].

School-aged children should not just be faced with school demands. Children need also to fulfill their needs. One such need is psychological well-being. Ryff (1995) [5] argues that psychological well-being is a condition in which the individual is not only free from demands or mental problems but also more than that, the condition of a person who has the ability to accept him or her-self and his or her life in the past and can do something to develop or grow him or her-self. The individual also has the ability to determine his own actions and the capacity to manage his or her life and environment effectively. In addition, these individuals have the belief that their lives are meaningful and purposeful, and have a positive relationship quality with others.

Children who have psychological well-being and can adapt well will be able to develop their potential [6]. These conditions can ultimately reduce the emergence of stress and increase the sense of comfort in him or her-self. Children can also adjust to the demands of everyday life especially those in school.

Current research has tried to balance between subjective and psychological well-being in children. Tennant et al (2007) [7] formulated the merging of both types of welfare into mental well-being. Therefore, it can be concluded that the emotional and psychological well-being of a child is a condition that balances the affective (emotional) condition as well as personal development and its relation to others (psychological).

Another study that has combined these two welfare approaches is done by Liddle and Carter (2015) [8]. Components of emotional and psychological well-being in children consisting of positive emotional state that represents the condition of individuals experiencing subjective wellbeing (hedonis). Here, the character of this component is indicated by cheerful behavior, feeling relaxed, or enjoying new things. Then, another aspect is the existence of a positive outlook that represents the concept of psychological well-being (eudaimonic) in children. Characteristics are characterized by self-belief, positive relationships with 
others, and optimism about the future. Based on the above explanation, it appears that there is an effort to merge the concept between the two types of well-being contained in one construct that is the emotional and psychological well-being of the child. Where the components include positive emotional state and positive outlook.

The Intervention School of Empathy (SoE) developed at the University of Leipzig, Germany, by Stueck [9] by conducting long-term research on TANZPRO-Biodanza in South America and Nonviolent Communication in Germany, Stueck found that there are emotional and psychological dependences on the integration between nonverbal (TANZPRO-Biodanza) and verbal aspects (NonViolence Communication). TANZPRO-Biodanza can increase the positive emotional in children by utilizing the work of the body system. Work is shown through the achievement of the balance of tension and relaxation conditions that occur in the body. The amygdala plays an important role in the emotional process of the TANZPRO-Biodanza session. The amygdala reaction will be even greater if the individual imitates a certain emotional expression. Correspondingly, emotional and psychological well-being can be achieved if the individual can balance the tension and relaxation that can create a positive emotional. Through TANZPRO-Biodanza, children become calmer and emerge positively emotionally. In other words, the child can achieve emotional and psychological well-being.

Research from Greaves, Stueck, and Svence (2016) [10] who conducted the study with participants aged 6-7 years. There are 22 sessions conducted with various measurements that include the emotional and social competence of the child. The number of subjects in the experimental group were 10 people and the control group were 9 children. The results show that there are significant changes, especially in the behavior of children who are internalized. In addition, there was a significant difference between the experimental group and the control group. Levels of cortisol (stress hormone) also showed a significant decrease. This also indicates an increase in the level of psychological well-being in the participants.

On the other hand, Nonviolence Communication serves as a means of emotional expression verbally. According to Stueck et al (2010) [9], the need to engage in speech-reflective activities is to distinguish feelings from emotions; also at the same time expressing and communicating human needs. The way to distinguish feelings is done verbally, such as choosing to ask instead of commanding. Correspondingly, when individuals can express what is perceived and desired indicates that the individual has achieved emotional and psychological well-being. Therefore, it can be said that through Nonviolence Communication, children can express what is felt and desired, so that children can also achieve emotional and psychological well-being.

The effectiveness of Non-Violent Communication (NVC) as part of the SoE is also demonstrated in the research by Schoppe and Stueck (2012) [11]. The research subjects are children aged 3-6 years as many as 45 people. The study design also involved a control group of 20 children. Furthermore, there is an increase in emotional social abilities in early childhood. They also show a decline in violation behavior and are able to develop adequate conflict resolution capabilities.

Based on the entire description, it shows that when following School of Empathy, children will learn to hone their emotional skills both nonverbally (TANZPRO-Biodanza) and verbally (Nonviolence Communication). Therefore, the changes indicate that the intervention is effective to improve the emotional and psychological well-being of the child. Hopefully, after the child finishes School of Empathy, the child will be able to apply emotional management ability in facing the demands of daily life especially that of in school. Thus, the condition shows that the child can achieve emotional and psychological well-being that can support the achievement of his or her potentials.

Therefore, based on the reasons presented, the researchers are interested to apply the School of Empathy training concept; especially in Yogyakarta. In this study, researchers restricted research into the realm of School of Empathy training to improve emotional and psychological well-being in elementary school-aged children in Yogyakarta. There are several hypotheses proposed in this study: There is difference in emotional and psychological well-being levels between the experimental group and the control group. There is a difference in the emotional and psychological well-being of the research subject before and after following the School of Empathy intervention.

\section{METHOD}

\section{A. Participants}

This study involved 13 children with age range 9-12 years in one public elementary school in Yogyakarta City which is divided into a 7 children in experimental group and a 6 children in control group.

\section{B. Material}

The research instruments used in this research are:

\section{1) Training module of school of empathy}

The module used in this study is a module developed by researchers from the School of Empathy Indonesia (SOEI) module developed by Stueck et al. (2010) [9]. SOEI is a method based on the results of scientific research on empathy and the development of an integral concept of empathy by German psychologist Marcus Stueck et al. (2010) [9].

Stueck, et al. (2010) [9] said that empathy is not just about feeling and thoughts, but also about biological, behavioral, affective, cognitive connection, communication, and attachment to human, animal, and plant in autopoiesis networks. According to Stueck, et al. (2010) [9] (1) Nonviolent Communication (NVC) by Marshal Rosenberg (Rosenberg, 2005) [12] and (2) Tanzpro-Biodanza by Rolando Toro (Stueck, 2010) [9]. The Blueprint of module as shown in Table I.

\section{2) Emotional and psychological well-being scale for} children

The scale for children is adapted from the scale of The 
Stirling Children's Well-being Scale (SCWBS) compiled by Liddle and Carter (2015) [8]. This scale consists of 15 items composed of 2 dimensions: Positive Emotional State (PES) of 6 items, Positive Outlook (POT) of 6 items, and the remainder ( 3 items) is an item to indicate the existence of social desirability. Each item has a choice of answers from 1 to 5 , where 1 means never, 2 means rare, 3 means sometimes, 4 means often, and 5 means always. The results of this scale test on 116 children showed the Alpha Cronbach coefficient of 0.760 .

TABLE I: BLUEPRINT OF SCHOOL OF EMPATHY TRAINING MODULE

\begin{tabular}{|c|c|c|}
\hline SESSION & MATERIAL & DURATION \\
\hline \multicolumn{3}{|l|}{ Day 1} \\
\hline Session 1 & Pre-test & \\
\hline & $\begin{array}{l}\text { Introduction and Learning Contract } \\
\text { Tanzpro }- \text { Spanyol }\end{array}$ & 30 minutes \\
\hline $\begin{array}{l}\text { Session } 2 \\
\text { Day } 2\end{array}$ & NVC - Introduction of Feelings and Needs & 30 minutes \\
\hline Session 3 & Tanzpro - Mesir & 60 minutes \\
\hline Session 4 & NVC - Observation of Feelings & 30 minutes \\
\hline Day 3 & & \\
\hline Session 5 & Tanzpro - Tanzania & 60 minutes \\
\hline $\begin{array}{l}\text { Session } 6 \\
\text { Day } 4\end{array}$ & NVC-Observation of Needs & 30 minutes \\
\hline Session 7 & Tanzpro - Chile & 60 minutes \\
\hline Session 8 & $\begin{array}{l}\text { NVC - Strategy of Needs Disclosure } \\
\text { Closing dan Post-test }\end{array}$ & $\begin{array}{l}30 \text { minutes } \\
30 \text { minutes }\end{array}$ \\
\hline
\end{tabular}

\section{Design}

This study used control group design with pre-test \& post-test. The dependent variables in this study are emotional and psychological well-being, while the independent variables are School of Empathy. This study uses 2 groups, i.e.: experimental group as the treatment group; the control group as the waiting list group.

The determination of experimental group and control group was done randomly. Measurements were performed twice in both experimental and control groups, i.e. before treatment and after treatment.

\section{Procedure}

Based on the selected research design, the following will explain the research procedures implemented in this study, i.e.:

1. Preparation of school of empathy module and SCWBS

2. Licensing of research and trial implementation

3. Conducting research with several processes: selecting research subjects, pre-test, randomly assigning research subjects, implementing School of Empathy interventions, and post-test.

\section{E. Statistical Analyses}

Data analysis used is quantitative analysis. Quantitative data analysis was performed to test the hypothesis by using statistical analysis that is the statistical test of independent sample t-test by comparing the post-test score of well-being between the experimental group and the control group. The analysis was also done by paired sample t-test by comparing the pre-test and post-test scores in the experimental group.

\section{RESULTS}

Descriptive data analysis from research subjects showed that the 2 study groups (Total $=13)$, experimental group $(\mathrm{N}=$ 7) and control group $(\mathrm{N}=6)$ had age ranged from 9-14 years old. By gender, they consist of 11 boys and 2 girls. The subject is scattered from grade 3-5 primary school. The children come from families with the level of socioeconomic status of middle to bottom. The school is located in a densely populated settlement with various backgrounds of the condition of the people around which fall into the category of downward socio-economic status.

The assumption test as t-test prerequisite has been fulfilled so that the researcher decided to use parametric analysis with t-test. The analysis was performed by comparing the well-being pre-post - post-test score between the experimental group and the control group. The analysis was performed by independent statistical test sample t-test with the result as shown in Table II.

TABEL II: THE RESULTS OF DIFFERENT TEST ANALYSIS BETWEEN EXPERIMENT AND CONTROL GROUP

\begin{tabular}{|c|c|c|c|c|c|c|c|}
\hline \multirow{3}{*}{$\begin{array}{l}\text { Variable } \\
\text { a }\end{array}$} & \multirow{3}{*}{$\mathrm{T}$} & \multirow{3}{*}{ df } & \multicolumn{3}{|c|}{ t-test for Equality of Means } & \multirow{2}{*}{\multicolumn{2}{|c|}{$\begin{array}{c}95 \% \\
\text { Confidence } \\
\text { Interval of } \\
\text { the Difference }\end{array}$}} \\
\hline & & & $\begin{array}{c}\text { Sig. } \\
\text { (2-tailed) }\end{array}$ & $\begin{array}{c}\text { Mean } \\
\text { Difference }\end{array}$ & $\begin{array}{c}\text { Std. } \\
\text { Error } \\
\text { Difference }\end{array}$ & & \\
\hline & & & & & & & Upper \\
\hline POT & -.305 & 11 & .766 & -.500 & 1.639 & -4.108 & 3.108 \\
\hline PES & -.540 & 11 & 600 & -619 & 1.147 & -3.144 & 1.906 \\
\hline WB & -.456 & 11 & 657 & -1.119 & 2.455 & -6.523 & 4.285 \\
\hline
\end{tabular}

From the result of independent sample t-test analysis it is seen that there is no difference of well-being score between experiment group and control group. In the experimental group $(\mathrm{M}=32.71, \mathrm{SD}=3.904)$ and control group $(\mathrm{M}=33.83$, $\mathrm{SD}=4.956) ;(\mathrm{t}(11)=-0.456, \mathrm{p}=0.657)$. On the aspect of positive emotional state $(\mathrm{t}(11)=-0.540, \mathrm{p}=0,6)$ and the aspect of positive outlook $(\mathrm{t}(11)=-0.540, \mathrm{p}=0,766)$.

Field (2009) [14] further states that the effect of treatment on the experimental design can be seen from the $r$ score that can be calculated by the formula $\mathrm{r}$. The calculation results are shown in Table III.

\begin{tabular}{|c|c|c|c|}
\hline Variable & $\mathrm{t}$ & df & $\mathrm{r}$ \\
\hline POT & -0.305 & $\begin{array}{l}1 \\
1\end{array}$ & $\begin{array}{c}0.091574560599368 \\
9\end{array}$ \\
\hline PES & -0.540 & $\begin{array}{l}1 \\
1\end{array}$ & 0.160700052000473 \\
\hline WB & -0.456 & $\begin{array}{l}1 \\
1\end{array}$ & 0.136207813526878 \\
\hline
\end{tabular}

From the calculations, it is seen that the effect size treatment scores (SoE training) on the children's well-being amount to $(r=0,136)$ positive emotional state amount to $(r=$ $0,160)$ and positive outlook amount to $(r=0,091)$. Field (2009) [13] states that score of effect size amount to \pm 0.1 shows a small effect.

The analysis was also done by comparing the pre-test and post-test scores in the experimental group. The analysis was done by paired sample $t$ test. The result of paired sample $t$ test as shown in Table IV.

TABEL IV: THE RESUlTS OF PRE-TEST AND POST-TEST ANALYSIS OF

\begin{tabular}{cccrr}
\multicolumn{5}{c}{ EXPERIMENT GROUP } \\
\hline Variable & $\mathrm{t}$ & $\mathrm{df}$ & $\mathrm{r}$ & Sig. (2-tailed) \\
\hline WB & -.823 & 6 & 0.31849194110314 & 5 \\
& & & .442 \\
POT & -1.000 & 6 & 0.37796447300922 & \\
& & & .356 \\
PES & -.410 & 6 & 0.16508520511946 & \\
& & & 6 & .696 \\
\hline
\end{tabular}


Based on paired sample t-test, it showed that there is no difference between pretest and posttest score on well-being variable $(\mathrm{t}(6)=-.823, \mathrm{r}=0.318, \mathrm{p}=0,442)$. On the aspect of positive outlook $(\mathrm{t}(6)=-1.000, \mathrm{r}=\mathrm{p}=0,356)$ as well on the aspect of positive emotional state $(\mathrm{t}(6)=-.410, \mathrm{r}=0.165$, $\mathrm{p}=0,696)$ ). However, based on the scores of $\mathrm{t}$ and $\mathrm{df}$, the researchers did the calculation to get the $\mathrm{r}$ score show the effect size score.

Based on $r$ calculations, it was found that the treatment (SoE training) gave an effect of 0.318 to the well-being in general. While in each aspect, SoE training gave greater effect on the positive outlook $(r=0.377)$ and smaller in the positive emotional state $(r=0.165)$. According to Field (2009) [13], $r$ with a score of \pm .3 means a moderate effect.

Comparison of scores between pre-test and post-test in the experimental group can be explained in Figure 1. The comparison scores are based on the pre-test and post-test scores of Positive Outlook (POT), Positive Emotional State (POS), and overall well-being. The comparison is presented in Fig. 1.

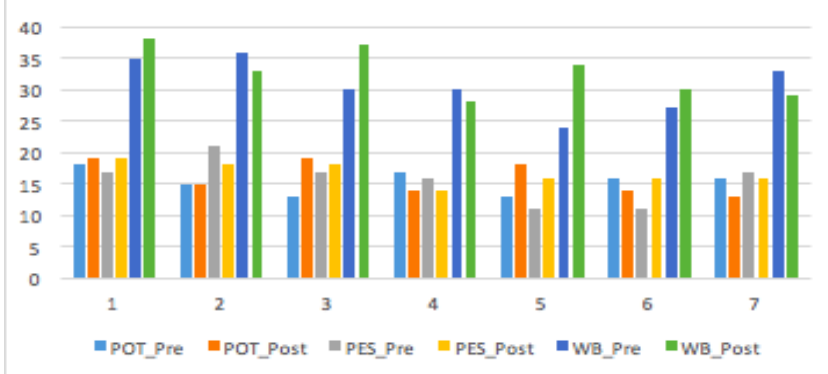

Fig. 1. Comparison of pre-test and post-test in the experimental group.

Based on the graph, it shows that in the experimental group, in general 3 of 7 subjects experienced an increase between before and after treatment (SoE training). The increase occurs in the positive outlook, positive emotional state, and well-being. On the other hand, 4 subjects tend to decrease scores on every aspect.

\section{DISCUSSION}

This study illustrates that no difference in emotional and psychological well-being was found between the experimental and control groups. Although the significance score shows insignificant results, Field (2009) [13] states that this does not show that the treatments have no effect at all. In this study, the SoE (School of Empathy) training has a small effect on the change of children's well-being levels.

In addition, there were no differences in the emotional and psychological well-being of the research subjects before and after the SoE training. Moore, Vandivere and Ehrle (2000) [14] states that children who are at a sociodemographic risk level are substantially more likely than other children to experience negative problems, such as emotional and behavioral problems and difficulties in school. This can underlie the SoE training in this study does not provide differences in the emotional and psychological well-being of children because the children involved as subjects of this study come from low sociodemographic.

But this SoE training generally has a moderate effect on the well-being level of children. When viewed in every aspect, SoE training has a greater effect on the positive outlook (POT) than the positive emotional state (POS) in children. This happens because in training, it gives children the ability to form positive relationships and build positive self-esteem so that according to Oades, Robinson and Green (2011) [15], children are positively involved with challenging tasks, and can adopt a positive outlook within their environment.

Limitations of this study can be made possible from less representative of the subject of the study into the sample. The sampling process needs to be adjusted to standards that hopefully can improve the validity of this study. In addition, there needs to be a development of a SoE training module that fits the culture that covers the lives of children.

\section{CONCLUSION}

This study demonstrates that the emotional and psychological well-being of children is not only determined by how children are taught to develop emotions both verbally and nonverbally but also by how family and environment conditions can affect the emotional and psychological well-being of children. This research can be used as a first step to develop appropriate interventions to improve the emotional and psychological well-being of children. Further research is expected to consider the sociodemographic conditions of the child as well as consider the number of representative samples. Overall, this study can guide practitioners to use SoE by considering sociodemographic condition and child culture.

\section{ACKNOWLEDGMENT}

The authors express our gratitude to Direktorat Penelitan dan Pengabdian Masyarakat (Directorate of Research and Community Service), Universitas Islam Indonesia, Yogyakarta, Indonesia who has provided support and research funding.

\section{REFERENCES}

[1] E. Hurlock, P. Anak, T. Meitasari, Z. Muslich, Penerjemah, Ed Ke-6., Jakarta: Erlangga, 2002

[2] N. G. Alvin, Handling Study Stress, Jakarta: Pt. Elex Media Komputindo, 2007.

[3] I. D. Auli, Studi Kasus Siswa Fobia Sekolah SDIT Slasabila 2 Klaseman, Sleman, Yogyakarta, Yogyakarta: Skripsi. Tidak Diterbitkan UIN Sunan Kalijaga, 2015.

[4] Desmita, "Psikologi perkembangan peserta didik," Bandung. Remaja, Bandung: Rosdakarya, 2005.

[5] C. D. Ryff, "Psychological well-being in adult life," Current Directions in Psychological Science, vol. 57, no. 6, pp. 99-104, 1995.

[6] J. F. Calhoun and J. R. Acocella, "Psychology of adjusment and human relationship," New York: Mc Graw Hill, Inc, 1995.

[7] R. Tennant, L. Hiller, R. Fishwick, S. Platt, S. Joseph, S. Weich, J. Parkinson, J. Secker, and S. S. Brown, "The warwick-edinburgh mental well-being scale(WEMWBS): Development and UK validation," Health and Quality of Life Outcomes, vol. 5, no. 63, pp. 2007.

[8] I. Liddle and G. F. A. Carter, "Emotional and psychological wellbeing in children: The development and validation of the stirling Children's well-being scale," Educational Psychology, vol. 31, no. 2, pp. 174-185. doi: 10.1080/02667363.2015.1008409, 2015.

[9] M. Stueck, A. Villegas, C. Luzzi, and R. Toro, "TANZPRO-children dance-oriented programs for children with TANZPRO-biodanza.," Unpublished Edition, Education Center for Health Upright., 2010. 
[10] V. Graves, M. Stueck, and G. Svence, "Changes of 1st grade school children's emotional and social competences in TANZPRO-Biodanza intervention group," in Proc. International Scientific Conference, pp. 344-356, 2016

[11] S. Schoppe and M. Stueck, "Wertschätzende kommunikation in kindertagesstätten evaluation eines programms zur empathieförderung und frühen gewaltprävention bei kindern.," Präv Gesundheitsf, vol. 7, pp. 229-236. doi: 10.1007/s11553-012-0352-3, 2012.

[12] M. Rosenberg, "Nonviolent communication: A language of life," 2nd Edition., California: Puddle Dancer Press., 2005.

[13] A. Field, "Discovering statistics using SPSS," 3rd edition, London: Sage Publication Ltd, 2009.

[14] K. A. Moore, S. Vandivere, and J. Ehrle, "Sociodemographic risk and child well-being," Washington, D.C.: Child Trends., 2000.

[15] L. G. Oades, P. Robinson, and S. Green, "Positive education: creating flourishing students, staff and schools.," InPsych, vol. 33, pp. 16-17, 2011.

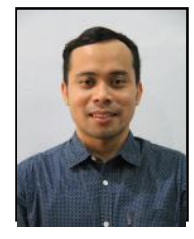

Nur Widiasmara was born in Purbalingga in 1985. He received his master's degree in master of professional psychology with the field of educational psychology at Universitas Islam Indonesia, Yogyakarta, Indonesia in year 2013. He is a member of Himpunan Psikologi Indonesia (Indonesian Psychological Association). He is a lecturer at Department of Psychology, Universitas Islam Indonesia. His research interest is based on educational/school psychology, positive psychology at school, and inclusive education.

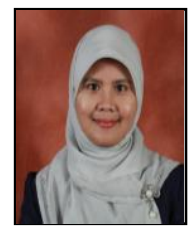

Resnia Novitasari was born in Yogyakarta in 1983. She received her master's degree in master of arts with the field of developmental psychology at Universitas Gadjah Mada, Yogyakarta, Indonesia in year 2013. He is a member of Himpunan Psikologi Indonesia (Indonesian Psychological Association). She is a lecturer at Department of Psychology, Universitas Islam Indonesia. Her research interest is based on child, developmental psychology and theory of mind.

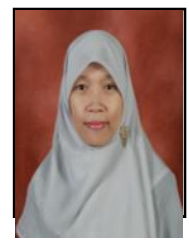

Nita Trimulyaningsih was born in Wonosobo in 1983. She received her master's degree in master of professional psychology with the field of clinical psychology at Universitas Gadjah Mada, Yogyakarta, Indonesia in year 2010. She is a member of Himpunan Psikologi Indonesia (Indonesian Psychological Association). She is a lecturer at Department of Psychology, Universitas Islam Indonesia. Her research interest is based on Islamic, clinical, biopsychology and community psychology.

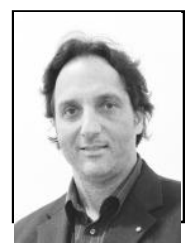

Marcus Stueck was born in Leipzig, Germany. He received his doctorate at the Institute of Applied Psychology, University of Leipzig (Dr. rer. nat. habilitus) in year 2007. He is a psychology professor of DPFA Hochschule Sachsen Germany. His research interest is based on counseling, emotion recognition, psychopathology, psychological assessment, and psychotherapeutic processes. 